\title{
タブー探索を用いたリカレント ニューラルネットワークの構造最適化
}

\author{
林田 智弘*・西崎 一郎 *・末宗 明恵*
}

\begin{abstract}
リカレントニューラルネットワークは，その構造抢よびユニット間の接続重みのパラメータを適切に設 定することで，時系列データに対して高い精度の予測が可能であるが，多数のユニットから構成されるリ カレントニューラルネットワークの構造を最適に設計することは難しい. また，ニューラルネットワーク の予測能力は学習用データに対する誤差の最小化だけではなく，学習に使用されない未知のデータに対す る汎化能力が必要である。本論文では，効率的近傍探索が期待できるタブー探索を用いた，汎化能力の獲 得も考虑したリカレントニューラルネットワークの構造最適化手法を提案する。いくつかの時系列データ に関するべンチマーク問題を用いた実験により，提案手法は，遺伝的アルゴリズムを用いた従来手法と比 ベて同等あるいはより優れた手法であることを示す.
\end{abstract}

キーワード：リカレントニューラルネットワーク，構造最適化，タブー探索，時系列データ，進化計算

\section{1. はじめに}

十分な数のユニットから構成されるニューラルネッ トワークは，ユニット間の接続重みなどのパラメータ を適切に設定することで, 任意の関数に対する高い近 似能力を持つことが知られており，文字認識[38]，音 声認識 [44], 文法推定[50]などの分類問題にフィード フォワード型ニューラルネットワーク (FNN：Feedfor ward Neural Network）が応用されている。また， ニューラルネットワーク内部でのフィードバックを考 慮したリカレントニューラルネットワーク (RNN： Recurrent Neural Network）が，株価予測[37]，気象 予測 [8]などの時系列データに対して高い予測精度を 持つことが報告されている.

ニューラルネットワークは, 構成するユニット数が 少ない場合には適切な学習を行うことが難しく, 逆に ユニット数が多すぎる場合には過学習による汎化能力 の低下が起こる。このため, ネットワークを構成する ユニットの数などのネットワーク構造を設計者が適切 に設定する必要があり, 設計者が試行錯誤的にネット ワークの構造を決定していた $[4,5,18,50]$.

ニューラルネットワークが高精度の近似, あるいは 予測能力を獲得するためには, 構成するユニット間の 接続重み, 学習ルール, ネットワーク構造などを最適

$\dagger$ Structural Optimization of Recurrent Neural Networks Using Tabu Search

Tomohiro HAYASHIDA, Ichiro NISHIZAKI and Akie SUEMUNE

* 広島大学大学院工学研究科

Graduate School of Engineering, Hiroshima University
に設定する必要がある [52]。しかし，対象問題に対応 した高い精度の予測能力を持つネットワークの構造を 決定するためには，多くの調整時間が必要であるた め, 遺伝的進化計算手法によりネットワークの適切な 構造を発見する手法 $[6,7,11,14,30,39,45,46,49]$ や, 接続重みを含めたネットワーク構造を遺伝的進化 手法により学習するTWEANN (Topology and Weight Evolving Artificial Neural Network) を基礎とした構造 最適化手法 $[35,40,41]$, ユニット間の伝達関数の最 適化手法 [34] などが提案されている。この他にも， ニューラルネットワークの最適化の関連研究が多く報 告されている [48]. 本論文では, 時系列データ予測の ためにニューラルネットワークの最適な構造を効率的 に発見する手法を提案する。

ここでは, 時系列データ予測に適した構造を持つ RNN の構造最適化手法をいくつか紹介する. Delgado et al. [11]は, SPEA2 [51]， NSGA-II [10]といっ た進化的多目的最適化手法を用いて, Elman 型 RNN [13] の学習誤差と構造の複雑さを最小化する構造最 適化手法を提案した。 Katagiri etal. [30]は, MCRNN (Multi-Context RNN) [20]を拡張したネットワークモ デルに対して局所最適解の保持やエリート保存, 自己 適応型突然変異 $[1,3,21]$ などの枠組みを応用した構 造最適化手法を提案した. Park [36]は, 入力層とフィー ドバック層からの出力の積をRNNの中間層に与える ニューラルネットワークであるBLRNN (BiLinear RNN) [53]の構造を単一の目的関数により評価し, 遺 伝的アルゴリズムを用いて定式化された目的関数を最 
小化する構造最適化手法を提案した.

これまでに提案されているニューラルネットワーク の構造最適化手法は, TWEAN $[40,41]$ のようにネッ トワーク構造と接続重みを進化的計算手法を用いて更 新する手法と, Delgado et al., Katagiri et al., Park な どのようにネットワーク構造は進化的計算手法により 更新し接続重みは䛊差逆伝播法を用いて更新する手法 の 2 種類に分類され，いずれの手法も主として遺伝的 アルゴリズムを基礎とした手法である。一方で, 類似 した構造を持つニューラルネットワークは類似したパ フォーマンスを持つと考えられるため, 近傍探索を基 礎とする手法を採用することで効率的な構造最適化が 行えると考えられる. 遺伝的アルゴリズムを用いるこ とで広範囲な解が探索されるが, このような近傍探索 を行うことは難しい。このため, 本論文では, 高精度 な時系列データ予測を目的としたニューラルネット ワークの構造最適化手法として, 遺伝的アルゴリズム ではなく近傍探索を基礎とするタブー探索[19]を用い た手法を提案する。ただし，時系列データに対する予 測問題を取り扱う従来研究 $[11,30,36]$ と同様に, 接 続重みの学習については誤差逆伝播法を用いる。ま た, 構造探索の集中化による局所解への収束を避ける ために，タブー探索のアルゴリズムを改良している. タブー探索は, 近傍探索を基礎としたメタヒューリス ティクスの一種であり，探索の集中化戦略と多様化戦 略の組み合わせにより効率的な解の探索が行われ，巡 回セールスマン問題 $[15,22]$, スパニングッリーの最 短経路問題 $[9,28,29]$ や，その他多くの最適化問題に 適用されている $[2,12,17,31,42]$.

また, ニューラルネットワークの学習では, 学習 データに対する誤差の最小化だけではなく，未知の データに対する汎化能力を持つように工夫されるべき である。ニューラルネットワークを用いた時系列デー タ予測においては, 過去数期分のデータをニューラル ネットワークに与えることで, 時系列データに対する 精度を高められる。しかし，十分な予測精度を得るた めに必要な過去のデータ量は, データによって変化す ると考えられる。このため, 対象となる時系列データ の予測のためにどの程度まで過去のデータを参照する かを決定する必要がある.

本論文では, 以上のことを複合的に考慮して, 時系 列データ予測に必要な過去のデータ量の決定も含め て, タブー探索を用いて高い予測精度と沉化能力を持 つようにニューラルネットワークの構造を最適化する 手法を提案する。なお, 提案手法の有効性の検証につ いては, 複数の時系列データのベンチマーク問題 $[16$, 24, 26, 43, 54]を用いる。
本論文の構成は以下のとおり，2 章では，ニューラ ルネットワークの構造扎よび関連研究について簡単に 紹介する。 3 章では, タブー探索を用いた構造最適化 手法について詳述し，4章でいくつかの時系列データ を用いた数值実験を行い, 従来手法との比較を行うと ともに提案手法の有効性を述べる. 最後に5 章でまと めと今後の課題を述べる.

\section{2 . ニューラルネットワークと構造最適化}

\section{1 ニューラルネットワークのモデル}

時系列データを取り扱う場合, 一般に過去のデータ をフィードバックすることでデータの予測精度が高く なることが期待される。このようなニューラルネット ワークのモデルとして，1期前の出力層からの出力を 中間層にフィードバックするJordan型ニューラルネッ トワーク [25]や，1期前の中間層からの出力をフィー ドバックするElman 型ニューラルネットワーク [13] などのRNN が提案されており, さまざまな時系列デー タ予測に適用されている $[8,11,30,37] . M C R N N[23]$ は, 数期前までの中間層からの出力を保持するための 複数のフィードバック層を持つ, Elman 型 RNN を拡 張したニューラルネットワークである。また, Elman 型 RNN は，入力層とフィードバック層からのデータ を中間層に与えるが, BLRNN[53]はこれらに加えて， 入力層とフィードバック層からの出力の積を RNN の 中間層に与える. Elman 型 RNN, MCRNN, BLRNN の構造をそれぞれ図 $1-3$ に示す.

時系列データ $y(t)=\left(y_{1}(t), y_{2}(t), \ldots, y_{O}(t)\right), t=1$, $2, \ldots$ を考えたとき,$t$ 期のデータ $y(t)$ は $, y(t-1), y$ $(t-2), \ldots$ にも依存していると考えられる。すなわ ち, 時系列データに対する予測とは, $y(t)=f(y(t-1)$, $y(t-2), \ldots)$ なる多変量関数 $f$ を同定することに帰着 される，厳密に $f$ を同定できれば，対象データの高精 度な予測が可能となるが, このような関数は複雑な非 線形関数であると考えられ，これを同定することは一

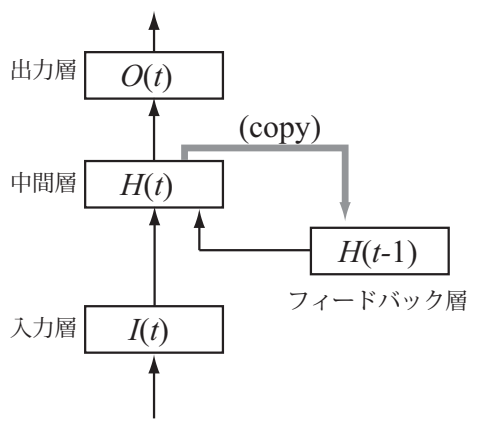

図 1 Elman 型 RNN 


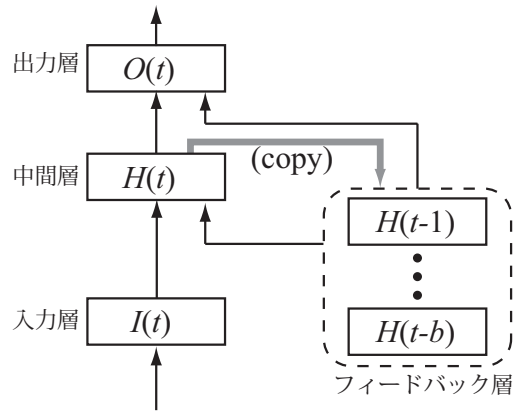

図 2 MCRNN

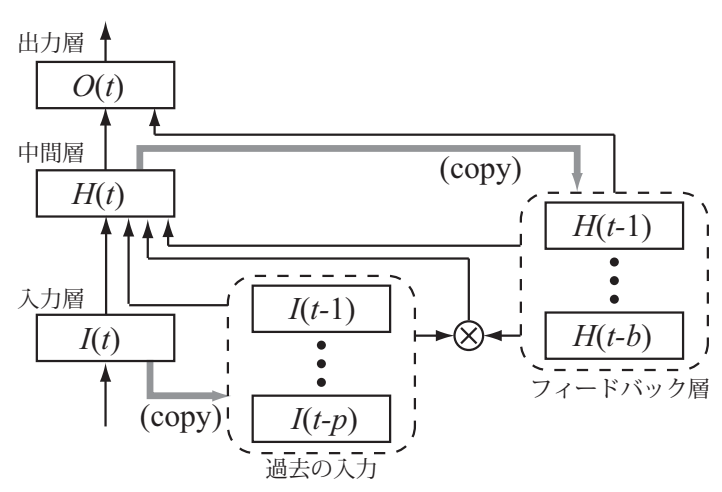

図 3 BLRNN

般に難しい。このため, 関数 $f$ に対する近似手法とし て, GP(Genetic Programming)などの進化的計算手 法を適用した手法が提案されている $[27,32]$. シグモ イド関数などの非線形な伝達関数を持つニューラル ネットワークが任意の非線形関数に対して高い近似能 力を持つことを考えれば， RNN は時系列データの予 測に対して高いパフォーマンスを持つといえる。この ため, $n$ 期前までのデータ $y(t-1), y(t-2), \ldots, y(t-n)$ を入力として与えるような構造を持つニューラルネッ トワークを用いた時系列データ予測が行われており， 精度の高いデータ予測に成功している $[11,30,36]$.

\section{2 ニューラルネットワークの構造最適化}

Delgado et al. [11]は, Elman 型 RNN の構造最適 化問題を, 学習誤差, 中間層ユニット数, 総接続数を それぞれ最小化する多目的最適化問題として定式化し た。非劣解を獲得するために NSGA-II [10］および SPEA2 [51]を適用した。

$\mathrm{RNN}$ の入力層, 中間層, 出力層のユニット数をそ れぞれ $n, h, o$ とし，ユニット間の接続の有無を表わ す接続マスクの長さを $l_{1}=h(n+h+o)$, ユニット間の 接続重みの数を $l g_{2}=h(n+h+o)$ として, 図 4 に示さ
れるような, 中間層ユニット数, 接続マスク, 接続重 みから構成される遺伝子 $s=\left(s_{1}, s_{2}, \ldots, s l_{1}+1, \ldots, s l_{2}+\right.$ $\left.\lg _{2}+1\right)$ を考える。

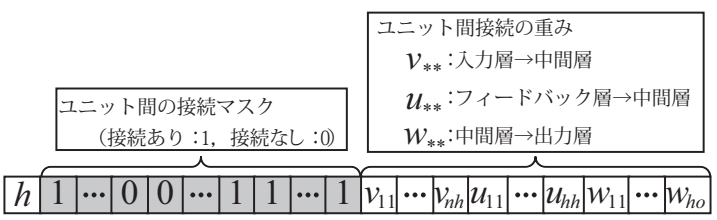

図 4 コード化された Elman 型 RNN

図 4 に示される構造を持つ 2 個の遺伝子が交叉する とき, 中間層ユニット数打よび接続マスクについては 一点交叉を適用し，接続重みに対して，Wrightの発 見的交叉 [47] 適用することで，中間層ユニット数 $h$ の変化によって変化する接続重み $v, u, w$ に関する 遺伝子座の対応関係を保持している.

突然変異については, 中間層ユニット数, および接 続マスクおよびユニット間接続の重みに対してそれぞ れ別々に突然変異が適用される。なお，中間層ユニッ 卜数 $h$ が変化する場合, ニューラルネットワークを構 成するユニット数が変化するため, $h$ が増加するとき には，接続マスクと接続の重みにランダムな数を割り 当てたものを追加する. $h$ が減少するときには, 対応 する接続マスクおよび接続の重みを削除する.

Delgado et al. は, RNNの構造最適化問題を, 誤差 $E=\frac{1}{T} \sum_{t} \sum_{s}\left(\psi_{s}(t)-y_{s}(t)\right)^{2}$, 中間層ユニット数, ユ ニット間接続を最小化するような，3つの目的関数

$\left.\begin{array}{l}\min E \\ \min h \\ \min \sum_{k=2}^{l g_{1}+1} s_{k}\end{array}\right\}$

として定式化した。

Elman 型 RNN では, 過去 1 期分の中間層からの出 力をフィードバックしているが, 過去数期分のデータ をフィードバックすることで時系列データの予測精度 が高くなると考えられる. Katagiri et al. [30]は, 過 去数期分の入力データを入力層および中間層に入力す るTDNN (Time-Delay Neural Network) [44]の構造 をMCRNN に導入し, 図 5 に示されるような, 複数 のフィードバック層を持つ拡張型 MCRNN に対する 構造最適化手法を提案した。

図 5 に示される通り, 拡張型 MCRNN は $b$ 層から 構成されるフィードバック層が中間層と出力層に接続 され, $p$ 期前までの入力データが中間層に接続されて いる. Katagiri et al. は, 式(1)に示される目的関数に, 


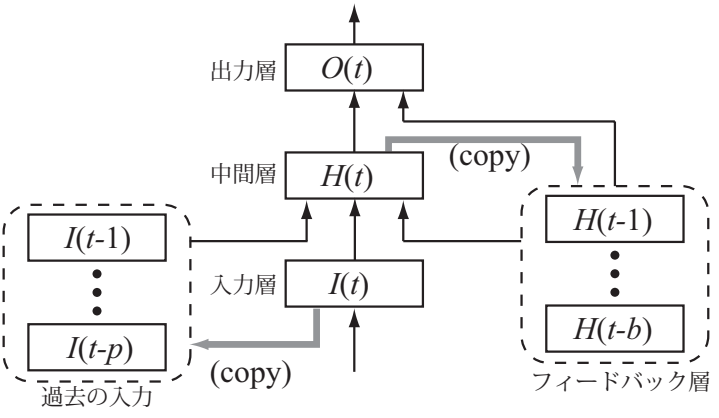

図 5 拡張型 MCRNN

フィードバック層数 $b$, 過去の入力の期数 $p$ を最小化 する目的関数を追加して, 拡張型 MCRNN の構造最 適化問題を多目的最適化問題として定式化した。拡張 型 MCRNN を図 4 と同様にコード化した場合, Elman 型 RNN よりも遺伝子が長くなるため，学習誤差への 影響が小さい接続に対する刈り取りを適用して構造探 索を効率化した。また，探索の集中化打よび多様化の ために，探索過程で局所最適解とされた個体および学 習誤差の小さい個体を一定数次世代に継承するエリー 卜保存則と, 自己適応型突然変異 [1]が適用されてい る.

Park [36]は, BLRNNの構造最適化問題に対して, 構造の評価関数をBLRNN を構成するユニット数と出 力誤差を用いて次のように定式化した。

$F=\frac{1}{1+E+C_{n} n+C_{h} h+C_{b} b}$

ただし $, n, h, b$ は入力層ユニット数, 中間層ユニッ 卜数, フィードバック層数, $C_{n}, C_{h}, C_{b}$ は重みパラ メータである. Park は式(2)に示す単一の目的関数を 最小化することで構造最適化を試みている，BLRNN の構造から, 中間層ユニット数の変化によりユニット 間接続の数の変化が大きくなるため， 3 つの重みパラ メータ $C_{n}, C_{h}, C_{b}$ について, $C_{h}$ に $C_{n}, C_{b}$ よりも大 きな值を割り当てることで効率的な探索が行われてい る.

\section{3. タブー探索を用いた構造最適化手法}

ニューラルネットワークの構造に関して, 類似した 構造をもつニューラルネットワークのパフォーマンス の差は大きくないが, 少しずつ改善していく方向へ構 造を調整していくことが可能である。このような調整 過程は近傍の集中的な探索とみなすことができ，実行 不可能な解も含めた広範囲な探索を行う遺伝的アルゴ リズムでは, ニューラルネットワークの構造最適化に
は有効であると考えられる解の近傍の集中的な探索が 困難である。従来研究では, 遺伝的アルゴリズムを用 いたニューラルネットワークの構造最適化手法が提案 されてきたが $[11,30,36]$, 遺伝的アルゴリズムによ る探索では, ニューラルネットワークの構造に関する 近傍を集中的に探索することが難しい。これに対し て, 近傍探索に基づく最適化手法であるタブー探索 [19]を用いることで, 類似した構造を集中的に探索す ることができる，さらに，多様化戦略を組み合わせる ことによって, 高いパフォーマンスを持つニューラル ネットワークの構造の発見が期待される.

MCRNN の構造は, 入力層, 中間層のユニット数, およびフィードバック層数により特徴づけられる。さ らに, 従来研究と同様にユニット間の接続を適切に選 択することで, MCRNN の沉化能力の向上が期待さ れる。本論文では, 図 2 に示されるMCRNN に対し て, 入力層, 中間層のユニット数, 打よびフィード バック層数の最適化にタブー探索 $[19]$ を適用したあ と, さらにユニット間の接続の有無の最適化に関して もタブー探索を適用して, 任意の時系列データに対す る高い予測精度を持つようにMCRNN の構造を最適 化する手法を提案する。すすなわち, 提案手法は 2 つの フェーズからなり，それぞれタブー探索に基づいた構 造最適化が行われる. 第 1 段階ではMCRNNを構成 するユニット数を決定し, 第 2 段階ではユニット間接 続の選択を行う。

\section{1 タブー探索を用いたユニット数の選択}

過去のデータの入力数 (入力層ユニット数) $n$, 中間 層ユニット数 $h$, フィードバック層数 $b$ で特徴づけら れる解を $A^{u}=(n, h, b)$ としてタブー探索を行い, 接 続重みを学習した後の近傍解を評価する。 ただし, 従 来のニューラルネットワークの構造最適化手法 [11, $30,36]$ と同様に, 接続重みおよび閾值は学習誤差の最 小化だけではなく未知のデータに対する汎化能力の獲 得も考慮する。

探索の集中化と多様化

タブー探索では短期メモリおよび長期メモリを用い た探索の集中化と多様化を実現している。 $g$ 回目の探 索における解を $A_{g}^{u}$ として, $A_{g}^{u}$ の各要素のうちの 1 つを 1 だけ増加，もしくは減少させた解の集合，すな わちハミング距離が 1 である解の集合 $\{(n-1, h, b)$, $(n+1, h, b),(n, h-1, b),(n, h+1, b),(n, h, b-1)$, $(n, h, b+1)\}$ に対して, これから短期メモリに記録 された解を除いたものを $A_{g}^{u}$ の近傍集合 $A N_{g}^{u}$ とする. 探索の集中化のために行われる近傍探索では, 現在の 解 $A^{u}$ の近傍のうちもっとも評価の高い解に移動し, 
これを次期の解とする。すでに探索した解を一定期間 短期メモリに記録し，この短期メモリに記録された解 への移動を禁止することで, 探索の巡回を防ぐ.

短期メモリを用いた近傍探索だけでは，一部の解領 域のみの探索となる場合がある。このため, 探索領域 をいくつかの部分領域に分割して各部分領域における 探索回数を保持する長期メモリを用いて，探索の多様 化を行う。 $d_{n}, d_{h}, d_{b}$ をそれ艺れ入力層ユニット数 $n$, 中間層ユニット数 $h$, フィードバック層数 $b$ に対応す る領域分割数， $w_{n}, w_{h}, w_{b}$ を対応する分割幅とした とき, 部分領域は, $F_{i j k}=\left\{\left(n_{i}, h_{j}, b_{k}\right) ;(i-1) w_{n}<\right.$ $\left.n_{i} \leqq i w_{n},(j-1) w_{h}<h_{j} \leqq j w_{h},(k-1) w_{b}<b_{k} \leqq k w_{b}\right\}$, $i=1, \ldots, d_{n}, j=1, \ldots, d_{h}, k=1, \ldots, d_{b}$ と表わされ る. 各部分領域に打いて近傍探索を繰り返す集中的な 探索が終われば，探索の多様化のため確率的に別の部 分領域に移動し，移動した小領域に含まれるように各 パラメータがランダムに決定された初期解が新たに生 成され探索が再開される。ここで， $L_{i j k}$ は部分領域 $F_{i j k}$ におけるこれまでの探索回数し，長期メモリに記 録される。部分領域 $F_{i j k}$ に移動する確率 $p_{i j k}$ は次式 で与えられる。

$$
p_{i j k}=\frac{L^{\text {range }}-L_{i j k}}{\sum_{i^{\prime}=1}^{d_{n}} \sum_{j^{\prime}=1}^{d_{h}} \sum_{k^{\prime}=1}^{d_{b}}\left(L^{\text {range }}-L_{f^{\prime} j^{\prime} k^{\prime}}\right)}
$$

ただし, $L^{\text {range }}=\max _{i, j, k} L_{i j k}-\min _{i, j, k} L_{i j k}$ である. 式(3)に より, これまでの探索回数が少ない部分領域が高い確 率で選択されやすくなり，広範囲の探索を可能にして いる.

加重䛊差による個体評価

学習過程に打けるニューラルネットワークの評価に はネットワークの出力と学習用データとの誤差が用い られるが, 本論文では, 過学習による沉化能力の低下 に対応するために, 汎化能力も考慮した解の評価を行 う。このために, 学習用データを学習用と検証用に二 分割し, 学習誤差と検証誤差のうち大きいものを最小 化することで，学習誤差が小さく汎化能力の高い ニューラルネットワークの獲得を目指す。ただし，本 論文で取り扱うような時系列データにおいて，ある時 刻のデータはそれ以前のデータに依存していることが 考えられるため，ある期を境界としてデータの分割を 行うことがのぞましい，本論文では特定の区間のデー タにのみ過剩に適合することを避けることと, 計算量 とのトレードオフを考慮してデータを 3 分割してこの 操作を 2 回行う. 図 6 に示されるように，学習用の時 系列データ $D$ を 3 分割したものを $D_{1}, D_{2}, D_{3}$ とす る。ただし，学習用の時系列データの時間的範囲を
$[0, T]$ としたとき，事前に決めた期 $T_{1}, T_{2}$ を $D_{1}, D_{2}$, $D_{3}$ の境界とする。

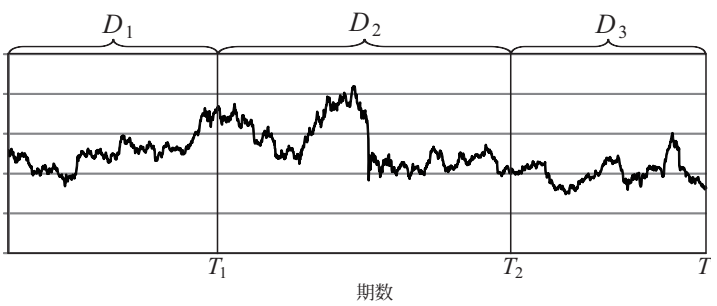

図 6 時系列データ $D$ の分割

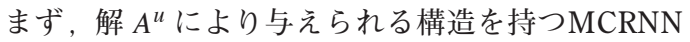
を用いて， $D_{1}$ で䛊差逆伝播法により接続重みを学習 し， $D_{2}$ で検証を行う. $0 \leqq \tau_{t} \leqq T_{1}<\tau_{v} \leqq T_{2}$ として 学習誤差を $e_{1}^{t}$, 検証誤差を $e_{1}^{v}$ とする. 次に, $D_{1} \cup D_{2}$ で学習, $D_{3}$ で検証を行い, $0 \leqq \tau_{t} \leqq T_{2}<\tau_{v} \leqq T$ と して, 学習䛊差を $e_{2}^{t}$, 検証䛊差を $e_{2}^{v}$ 計算する。こ こで, 対象データをo次元の時系列データとしたと き, $t$ 期目に打ける， $s$ 番目のデータのニューラルネッ トワークからの出力を $\psi_{s}(t)$, 教師信号となる時系列 データを $y_{s}(t)$ として, 式(4)により誤差を計算する.

$$
\left.\begin{array}{ll}
e_{i}^{t}=\sum_{\tau_{t}} \sum_{S=1}^{o}\left(\psi_{s}\left(\tau_{t}\right)-y_{s}\left(\tau_{t}\right)\right)^{2}, & i=1,2, \\
e_{i}^{V}=\sum_{\tau_{V}} \sum_{S=1}^{o}\left(\psi_{s}\left(\tau_{V}\right)-y_{s}\left(\tau_{V}\right)\right)^{2}, & i=1,2 .
\end{array}\right\}
$$

解 $A^{u}$ はこれらの誤差を用いて,

$$
\begin{array}{r}
E_{V}\left(A^{u}\right)=\lambda \max \left(e_{1}^{t}, e_{1}^{V}\right)+(1-\lambda) \max \left(e_{2}^{t}, e_{2}^{V}\right), \\
\lambda \in[0,0.5]
\end{array}
$$

により評価する。本論文では $E_{v}\left(A^{u}\right)$ を解 $A^{u}$ に対応 するMCRNNの加重誤差とよぶ. な打解 $A^{u}$ は, 対応す るユニット数を持つMCRNN に対して，すべてのユ ニット間接続が存在するものとして, 誤差逆伝播によ り接続重みを更新した後, 加重誤差(5)によりMCRNN を評価する。これにより, 学習誤差と検証䛊差をどち らも小さくするような構造のMCRNN が高く評価さ れる。このような個体評価の方法は, 交差検定の応用 であり，加重誤差 (5)が高い個体は未知のデータに対 する高い予測能力を持つことが期待される.

一定期間，上記タブー探索により加重誤差の最良值 が更新されない，もしくは一定回数の探索が行われれ ば，MCRNNを構成するユニット数を確定し，次節 に示す手順でユニット間接続の選択を行う。 


\section{2 ユニット間接続の選択}

ニューラルネットワークを構成するユニット数が適 切に決定されれば，学習精度および未知のデータに対 する予測精度の両方が高くなると考えられる。さら に, ユニット間の接続の有無についても, 適切に設定 することができれば予測精度の向上が期待される.こ のため, 本論文では, 3.1 節で述べた手順で, 入力層 ユニット数, 中間層ユニット数, フィードバック層数 が決定された後, 構造最適化の第 2 段階として, タ ブー探索を用いてユニット間接続の選択を行う。

まず, 探索の効率化のために重要性の低い接続を削 除したものを初期解としてタブー探索を行う。 3.1 節 で得られたMCRNNに対して，ユニット間の接続を 1 本削除し, 加重誤差(5) が小さくなる場合, その接 続は重要性の低い接続と判断して削除する [30]。これ を接続の刈り取りといい, 順番に接続の刈り取りを 行ったものを初期解として, タブー探索を用いてユ ニット間の接続の選択を行う。

図 7 に示されるようなユニット間の接続に関する接 続マスクにより特徴づけられる解を $A_{s}^{l}$ とする。 ただ し, $A_{s}^{l}$ は $s$ 回目の探索における解である. $A_{s}^{l}$ からハ ミング距離が 1 の解の集合から短期メモリに記録され た解を除いたものを $A_{s}^{l}$ の近傍集合 $A N_{s}^{l}$ とする。

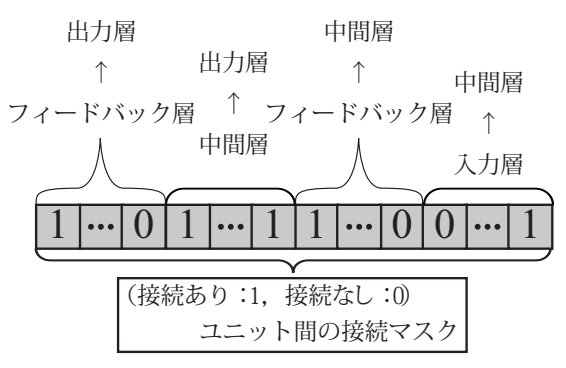

図７コード化された接続マスク (解 $\left.A_{s}^{l}\right)$

ただし，ユニット間接続の選択において接続を削除 することは，接続重みを０にすることと同義であ る. 有望な初期解を設定していることから, 探索の効 率化のために第 2 段階のタブー探索では短期メモリ による集中的な探索のみを行う。また, 近傍解の評価 は第 1 段階のタブー探索と同様に, 加重誤差(5)によ り評価する。

\section{3 構造最適化手法のアルゴリズム}

2 段階のタブー探索を用いたMCRNN のユニット 数とユニット間の接続の決定に基づき, 構造最適化を 行う. 提案手法のアルゴリズムの概要は以下のとおり.

Step 1. (初期化) 初期解 $A_{0}^{u}=(n, h, b)$ をランダムに
生成し, $A_{b e s t}^{u}=A_{0}^{u}$ とする. $g=1$ として, Step 2 に 進む。

Step 2. (ユニット数の決定)

Step 2-1. 解 $A_{g-1}^{u}$ の近傍集合 $A N_{g-1}^{u}$ のうち加重誤 差(5)が最も小さい解を, $A_{g}^{u}$ とする.

Step 2-2. $E_{v}\left(A_{g}^{u}\right)<E_{v}\left(A_{\text {best }}^{u}\right)$ が成り立つ場合, $A_{\text {best }}^{u}=$ $A_{g}^{u}$ として $A_{b e s t}^{u}$ を短期メモリに追加的に記録する。こ のとき, 短期メモリに記録されている解の数が一定数 以上の場合, 最も古く記録された解を短期メモリから 削除する。一定期間最良解の更新が行われない, ある いは一定回数の近傍探索が行われたら短期メモリを更 新してStep 2-3へ. そうでなければ $g=g+1$ として Step $2-1 へ$.

Step 2-3. 再初期化が一定回数行われる, あるいは 一定期間最良解の更新がなければStep 3 へ。 そうで なければ, 解の再初期化を実施する。すなおち, 長期 メモリから定義される式(3)を用いて現在の解とは異 なる部分領域で新たな初期解を生成し, 長期メモリを 更新してStep 2-1へ.

Step 3. (ユニット間接続の選択)

Step 3-1. 現在の最良解 $A_{\text {best }}^{u}$ に対応するMCRNN に含まれる接続のうち, 削除することで加重䛊差 $E_{v}$ が小さくなる接続を削除したものを, 接続選択の初期 解 $A_{0}^{l}$ とし,$A_{\text {best }}^{l}=A_{0}^{l}$ とする. $s=1$ としてStep 3-2 $\sim$.

Step 3-2. $A_{s-1}^{l}$ の近傍集合 $A N_{s-1}^{l}$ のうち加重䛊差 (5) が最も小さいものを現在の解 $A_{s}^{l}$ として, 短期メモ リを更新する。

Step 3-3. $E_{v}\left(A_{s}^{l}\right)<E_{v}\left(A_{\text {best }}^{l}\right)$ が成り立つ場合, $A_{\text {best }}^{l}=$ $A_{s}^{l}$ とする.

Step 3-4. Step 3-2，3-3 を一定回数繰り返した ら， $A_{\text {best }}^{l}$ を解として終了する. そうでなければ $s=$ $s+1$ としてStep 3-2へ.

提案手法では, Step 2 でユニット数の決定, Step 3 でユニット間の接続がそれぞれ行われる。

\section{4. 数値実験}

複数の時系列データのベンチマーク問題により提案 手法の有効性を検証する。提案手法を適用する時系列 データとして, 太陽黒点数データ (SSD) [54], レー ザー生成データ (LGD) [16], K.U.Leuven データ (KUL) [43], Mackey-Glass カオス時系列データ（MGC） [33], Box-Jenkins 溶鉱炉データ (BJF) [55], 星の輝 度データ (SLD) [56], IMB 株価データ (IBM) [56], 放射能測定装置温度データ (RAT) [56]の 8 種類を用い る。

本論文では, 時系列データを学習用データと汎化能 
力測定用データとして 2 分割し, 8 種類のベンチマー ク問題に対してそれぞれ30試行ずつのシミュレーショ ン実験を行う。すなわち, 学習用データは提案手法に おいて図 6 に示されるようにさらに 3 分割され，学習 および検証用に用いられる。学習用データに対する誤 差は， $\lambda=0.4$ とした加重誤差(5)により評価するもの とし, 汎化能力測定用データに対する誤差の最小值, 最大值, 平均值によりニューラルネットワークの構造 最適化手法の評価を行う。ただし， $T_{g}$ 期分の汎化能力 測定用データに関する時刻 $\tau_{g}$ における誤差を $\sum_{S=1}^{O}$ $\left(\psi_{s}\left(\tau_{g}\right)-y_{s}\left(\tau_{g}\right)\right)^{2}$ としたとき, 汎化能力測定用データ に対する誤差は, $\frac{1}{T_{g}} \sum_{\tau_{g}} \sum_{S=1}^{O}\left(\psi_{s}\left(\tau_{g}\right)-y_{s}\left(\tau_{g}\right)\right)^{2}$ によ
表 1 時系列データの期数

\begin{tabular}{|l|r|r|r|}
\hline & 全期数 & $\begin{array}{c}\text { 学習用 } \\
\text { (期数) }\end{array}$ & $\begin{array}{c}\text { 汎化能力 } \\
\text { 測定用 (期数) }\end{array}$ \\
\hline SSD & 307 & 270 & 37 \\
\hline LGD & 1600 & 1400 & 200 \\
\hline KUL & 2000 & 1700 & 300 \\
\hline MGC & 1200 & 1000 & 200 \\
\hline BJF & 296 & 270 & 26 \\
\hline SLD & 600 & 500 & 100 \\
\hline IBM & 3332 & 3000 & 332 \\
\hline RAT & 4324 & 3500 & 824 \\
\hline
\end{tabular}

表 2 実験結果

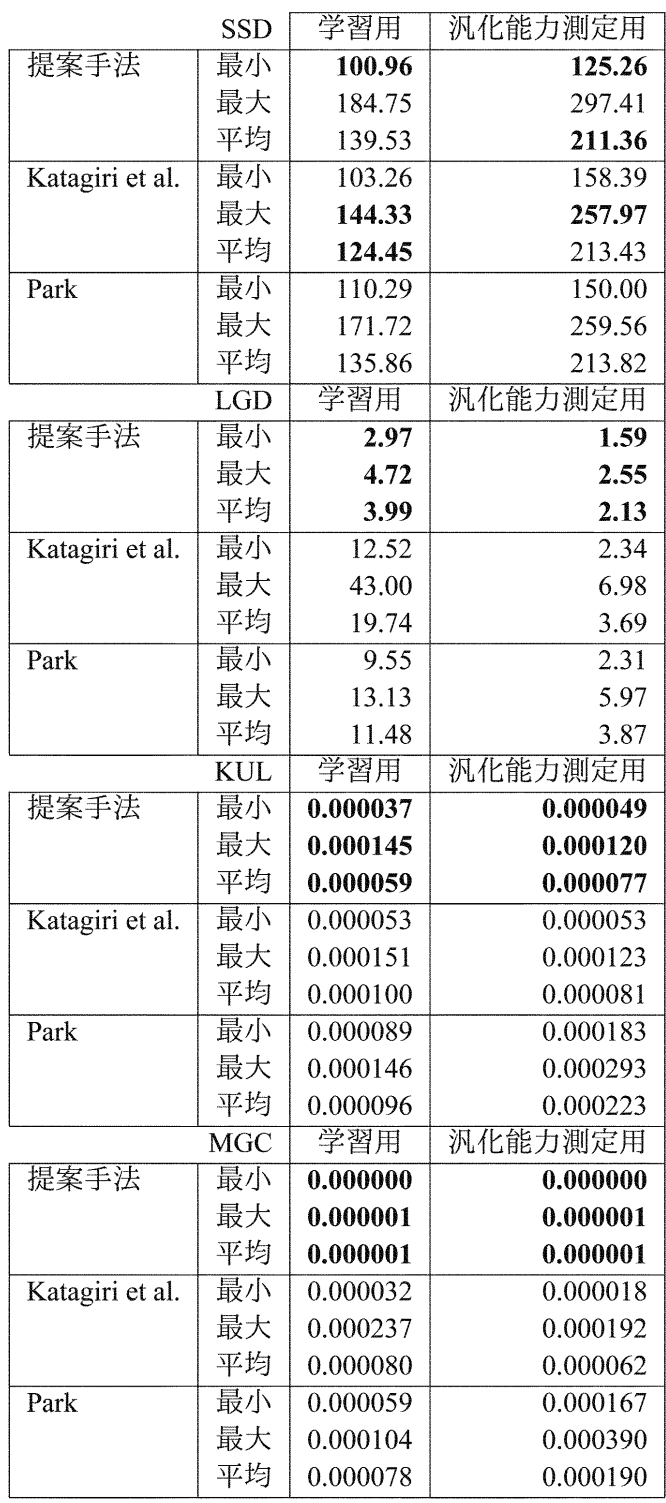

\begin{tabular}{|c|c|c|c|}
\hline & $\mathrm{BJF}$ & 学習用 & 沉化能力測定用 \\
\hline \multirow{3}{*}{ 提案手法 } & 最小 & 0.0468 & 0.1802 \\
\hline & 最大 & 0.0661 & 0.4515 \\
\hline & 平均 & 0.0523 & 0.2872 \\
\hline \multirow[t]{3}{*}{ Katagiri et al. } & 最小 & 0.0483 & 0.0147 \\
\hline & 最大 & 0.0604 & 0.0698 \\
\hline & 平均 & 0.0526 & 0.0379 \\
\hline \multirow[t]{3}{*}{ Park } & 最小 & 0.0568 & 0.5854 \\
\hline & 最大 & 0.0597 & 0.6790 \\
\hline & 平均 & 0.0586 & 0.6448 \\
\hline & SLD & 学習用 & 沉化能力測定用 \\
\hline \multirow[t]{3}{*}{ 提案手法 } & 最小 & 0.0169 & 0.0165 \\
\hline & 最大 & 0.0630 & 0.1014 \\
\hline & 平均 & 0.0387 & 0.0475 \\
\hline \multirow[t]{3}{*}{ Katagiri et al. } & 最小 & 0.2322 & 0.2382 \\
\hline & 最大 & 0.4007 & 0.3820 \\
\hline & 平均 & 0.2654 & 0.2740 \\
\hline \multirow[t]{3}{*}{ Park } & 最小 & 0.2147 & 0.2457 \\
\hline & 最大 & 0.3132 & 0.3760 \\
\hline & 平均 & 0.2428 & 0.2618 \\
\hline & IBM & 学習用 & 汎化能力測定用 \\
\hline \multirow[t]{3}{*}{ 提案手法 } & 最小 & 2.585 & 1.529 \\
\hline & 最大 & 2.630 & 1.991 \\
\hline & 平均 & 2.602 & 1.658 \\
\hline \multirow[t]{3}{*}{ Katagiri et al. } & 最小 & 2.522 & 1.523 \\
\hline & 最大 & 2.604 & 1.928 \\
\hline & 平均 & 2.557 & 1.690 \\
\hline \multirow[t]{3}{*}{ Park } & 最小 & 2.809 & 1.641 \\
\hline & 最大 & 2.973 & 1.851 \\
\hline & 平均 & 2.906 & 1.718 \\
\hline & RAT & 学習用 & 沉化能力測定用 \\
\hline \multirow[t]{3}{*}{ 提案手法 } & 最小 & 0.1598 & 0.2045 \\
\hline & 最大 & 0.2082 & 0.3021 \\
\hline & 平均 & 0.1776 & 0.2331 \\
\hline \multirow[t]{3}{*}{ Katagiri et al. } & 最小 & 0.1770 & 0.1270 \\
\hline & 最大 & 0.1868 & 0.1355 \\
\hline & 平均 & 0.1797 & 0.1308 \\
\hline \multirow[t]{3}{*}{ Park } & 最小 & 0.1812 & 0.1700 \\
\hline & 最大 & 0.1870 & 0.1849 \\
\hline & 平均 & 0.1847 & 0.1773 \\
\hline
\end{tabular}


り評価される。

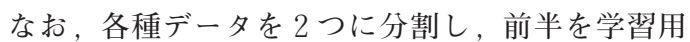
データとして, 後半を汎化能力検証用データとして用 いる． 3.1 節で述べたように，加重䛊差(5)を評価する ために学習用データをさらに 3 分割する。ただし，

Katagiri et al. および Park の構造最適化手法は，そ れぞれ拡張型 MCRNN，BLRNN を構造最適化を行う ネットワークの対象として, 本論文の提案手法はこれ らのネットワークよりも単純な構造を持つMCRNN を構造最適化を行う対象のネットワークとする。図 2 ， 3，5より，BLRNN，拡張型 MCRNN は，過去の データを入力する期数を $p=0$ とすれば MCRNN と 同様の構造となる.

各ベンチマーク問題の全期数, 学習用データと検証 用データの期数を表 1 に示す。

ニューラルネットワークを用いた 8 種類の時系列 データ予測に対して, Katagiri et al. や, Park と本論 文の提案手法を適用した結果を表 2 に示す. 各項目に ついて，3 種類の手法で最も䛊差が小さく予測精度の 高い結果は太字で示される。ただし, 本論文では各構 造最適化手法の比較のために同一の計算機を用いて実 験を行った。

ここで, 本論文ではより高いパフォーマンスを持つ 構造を発見することが重要であると考え, 䛊差の最小
値により 3 種類の手法を比較する。表 2 より, 学習用 データに対する誤差の最小值を見ると, IBM 以外で 提案手法が最小となって扔り, 䛊差の平均值について も, SSD, IBM 以外で提案手法が最小となってい る。また, SSD, IBMの学習用データに対する誤差 は, 従来手法とほぼ同程度となっている。ささらに, 汎 化能力測定用データに対する䛊差についても, BJF, IBM, RAT 以外で提案手法が最小となって打り, IBM では従来手法とほぼ同等で, 概ね従来手法に比 べて提案手法は高い汎化能力を獲得できたことがわか る.したがって, 時系列データの学習用データと汎化 能力測定用データに対する予測䛊差がともに小さいこ とから, 提案手法の適用によってニューラルネット ワークの予測精度が高くなるような構造を発見するこ とに成功したといえる。特に, LGDでは, 提案手法 は従来手法に比べて良好な結果を得ている。 LGD は 前半 $5 \%$ を除いて規則的な振動を繰り返すデータであ り，このような規則性の高い時系列データに対して提 案手法は, 従来手法と比べて特に高い予測精度を得る ことができた。

数值実験の結果に対して, 有意水準を $5 \%$ とした Wilcoxonの符号付順位和検定を行った結果, 誤差の 最小值は学習用データおよび汎化能力測定用データの 両方で提案手法と従来手法に有意に差があり, 誤差の

表 3 入力層, 中間層ユニット数・フィードバック層数

\begin{tabular}{|c|c|c|c|c|}
\hline & 入力層ユニット数 & 中間層ユニット数 & フィードバック層数 \\
\hline \multirow[t]{3}{*}{ SSD } & 最小 & 1 & 2 & 0 \\
\hline & 最大 & 7 & 10 & 5 \\
\hline & 平均 & 5.6 & 4.0 & 1.8 \\
\hline \multirow[t]{3}{*}{ LGD } & 最小 & 8 & 5 & 1 \\
\hline & 最大 & 12 & 14 & 4 \\
\hline & 平均 & 9.6 & 7.3 & 2.3 \\
\hline \multirow[t]{3}{*}{ KUL } & 最小 & 1 & 1 & 0 \\
\hline & 最大 & 2 & 31 & 8 \\
\hline & 平均 & 2.0 & 6.9 & 1.7 \\
\hline \multirow[t]{3}{*}{ MGC } & 最小 & 23 & 7 & 2 \\
\hline & 最大 & 27 & 8 & 2 \\
\hline & 平均 & 25.0 & 7.5 & 2.0 \\
\hline \multirow[t]{3}{*}{ BJF } & 最小 & 4 & 3 & 0 \\
\hline & 最大 & 6 & 12 & 0 \\
\hline & 平均 & 4.1 & 6.3 & 0.0 \\
\hline \multirow[t]{3}{*}{ SLD } & 最小 & 24 & 2 & 0 \\
\hline & 最大 & 42 & 8 & 10 \\
\hline & 平均 & 31.1 & 4.6 & 1.3 \\
\hline \multirow[t]{3}{*}{ IBM } & 最小 & 1 & 2 & 0 \\
\hline & 最大 & 2 & 11 & 0 \\
\hline & 平均 & 1.0 & 6.5 & 0.0 \\
\hline \multirow[t]{3}{*}{ RAT } & 最小 & 1 & 2 & 0 \\
\hline & 最大 & 3 & 8 & 3 \\
\hline & 平均 & 1.2 & 4.5 & 1.5 \\
\hline
\end{tabular}


最大值および平均值については有意水準を $10 \%$ として も有意に差があるとはいえないことが明らかとなっ た。前述のとおり, MCRNN は, 拡張型 MCRNN や BLRNN の特殊な構造の 1 つでありネットワーク構造 が単純であるにも関わらず，これらのネットワークに 対する構造最適化手法 $[30,36]$ と比べて, 提案手法は 複数回の試行に打ける誤差の最小值については優れた 結果が得られており, 最大值や平均值などについては 同等の結果が得られた。このことからも，本論文で提 案するタブー探索を用いたニューラルネットワークの 構造最適化手法は, 時系列データ予測のための有効な 手法であるといえる.

表 3 に, 提案手法により獲得した MCRNN の入力 層ユニット数 $n$, 中間層ユニット数 $h$, フィードバッ ク層数 $b$ の最小值, 最大值, 平均值を示す.

表 3 より, MGC PSLD は他の問題よりも入力層工 ニット数が多い．これらのベンチマーク問題は他の問 題に比べて周期性の高いデータであり, この結果から も，周期性の高い時系列データの予測には，過去の データが多く必要であることがわかる。

一般に，ニューラルネットワークを構成するユニッ 卜数が大きくなると, 学習誤差は小さくなるが検証誤 差が大きくなる。しかし，表 2, 3 より，MGC やSLD では，ユニット数が多いにも関わらず，学習誤差と検 証誤差はともに小さい.ニューラルネットワークの汎 化能力を考慮した加重誤差(5), 打よび，時系列デー 夕予測に必要な過去のデータの期間数である入力層工 ニット数も含めた構造探索を行うことで, 学習データ のみならず未知の時系列データ予測に対する高い汎化 能力を持つ, 適切な構造のニューラルネットワークを 獲得できたと考えられる。

\section{5 . おわりに}

本論文では，タブー探索法を用いてMCRNNの入 力層ユニット数, 中間層ユニット数, フィードバック 層数打よび, 各ユニット間の接続を選択する構造最適 化手法を提案した。従来研究における進化的計算手法 を用いたニューラルネットワークの構造最適化は, 遺 伝的アルゴリズムに基づく手法が数多く提案されてき た。これに対して, 本論文の提案手法は, 高いパ フォーマンスを持つニューラルネットワークに似た構 造をタブー探索を用いて集中的に探索する手法である. MCRNN は, 拡張型 MCRNN PBLRNN よりも単純 な構造を持つが，複数の時系列データによる数值実験 では, 従来手法 $[30,36]$ とほぼ同等，あるいはより 優れた結果を得ることができた。

一方で, 汎化能力が従来手法よりも若干低くなるよ
うな結果もあったため，そのようなデータを分析し， データの特性とニューラルネットワークの構造の関係 を明らかにすることによる, 手法の改善が今後の課題 として考えられる。

\section{参 考 文 献}

[1] S. Agrawal, Y. Dahora, M.K. Tiwari and Y.- J. Son: Interactive particle swarm: A Pareto-adaptive metaheuristic to multiobjective optimization, IEEE Stansaction, System, Man, and Cybernectics A: Systems and Humans 38, pp.258-277, 2008.

[2 ] M. Arikan and S. Erol: A hybrid simulated annealingtabu search algorithm for the part selection and machine loading problems in flexible manufacturing systems, International Journal of Advanced Manufacturing Technology 59, pp.669-679, 2012.

[ 3 ] T. Back and M. Schutz: Intelligent mutation rate control in canonical genetic algorithms, Proceedings of 9th International Symposium on Foundations of Intelligent Systems, ser. LNAI, Z.W. Ras and M. Michalewicz (eds.), Berlin, 3, pp.158-167, 1996.

[ 4 ] A. Blanco, M. Delgado and M.C. Pegalajar: Fuzzy grammatical interence using neural networks, Mathware and Soft Computing 5, pp.133-140, 1998.

[ 5 ] A. Blanco, M. Delgado and M.C. Pegalajar: Fuzzy automation induction using neural network, International Journal of Approximate Reasoning 27, pp.1-26, 2001.

[ 6 ] X. Cai, Z. Zhang, G. Venayagamoorthy and D. Wunsch: Time series prediction with recurrent neural networks using a hybrid PSOEA algorithm, Proceedings of International Joint Conference on Neural Networks \& IEEE International Conference on Fuzzy Systems, Budapest, Hungary, pp.1647-1652, 2004.

[ 7 ] F.E. Cellier and A. Nebot: Multi-resolution timeseries prediction using fuzzy inductive reasoning, Proceedings of International Joint Conference on Neural Networks \& IEEE International Conference on Fuzzy Systems, Budapest, Hungary, pp.1621-1624, 2004.

[ 8 ] T.W.S. Chow and C.T. Leung: Neural network based short- term load forecasting using weather compensation, IEEE Power \& Energy Magazine 11, pp.1736$1742,1996$.

[ 9 ] R. Cordone and G. Passeri: Solving the quadratic minimum spanning tree problem, Applied Mathematics and Computation 218 pp.11597-11612, 2012.

[10] K. Deb, A. Pratap, S. Agrwal and T. Meyarivan: A fast and elitist multiobjective genetic algorithm: NSGAII, IEEE Transactions on Evolutionary Computation 6, pp.182-197, 2002.

[11] M. Delgado, M.P. Cuellar, M.C. Pegalajar: Multiobjective hybrid optimization and training of recurrent neural networks, IEEE Transactions on Systems, Man, and Cybernetics-Part B: Cybernetics 38, pp.381-403, 2008.

[12] A. Duarte and R. Marti: Tabu search and GRASP for the maximum diversity problem, European Journal 
of Operational Research 178, pp.71-84, 2007.

[13] J.L. Elman: Finding structure in time, Cognitive Science 14, pp.179-211, 1999.

[14] J. Fang and Y. Xi: Neural network design based on evolutionary programming, Artificail Intelligent Engineering 11, pp.155-161, 1997.

[15] M. Gendreau, G. Laporte and D. Vigo: Heuristics for the traveling salesman problem with pickup and delivery, Computers \& Operations Research 26, pp.699714, 1999.

[16] G. Gershenfeld and A. Weigend: The Santa Fe time series competition data," 1991[online]. Available: http://wwwpsych. stanford.edu/ andreas/Time-Series/SantaFe.html.

[17] F. Geyik and I.H. Cedimoglu: The strategies and parameters of tabu search for job-shop scheduling, Journal of Intelligent Manufacturing 15, pp.439-448, 2004.

[18] C. Giles, C. Miller, D. Chen, H. Chen, G. Sun and Y. Lee: Learning and extracting finite state automate with second order recurrent neural networks, Neural Computation 4, pp.393-405, 1992.

[19] F. Glover and M. Laguna: Tabu Search, Kluwer Academic Publishers, 1997.

[20] B.Q. Huang, T. Rashid and M.-T. Kechadi: Multicontext recurrent neural network for time series applications, International Journal of Information and Mathe-matical Sciences 3, pp.45-54, 2007.

[21] F. Herrera, M. Lozano and J.L. Verdegay: Tackling real-coded genetic algorithms: Operators and tolls for behavioral analysis, Artificial Intelligence Review 12, pp.265-319, 1998.

[22] Y.F. Hung and W.- C. Chen: A heterogeneous cooperative parallel search of branch-and-bound method and tabu search algorithm, Journal of Global Optimization 51, pp.133-148, 2011.

[23] B.Q. Huang, T. Rashid and M.-T. Kechadi: Multicontext recurrent neural network for time-series application, International Journal of Computational Intelligence 3, pp.45-54, 2006.

[24] R. Hyndman: Time series data library, [online]. Available: http://www.robjhyndman.com/TSDL/ index.htm.

[25] M.I. Jorda: Attractor dynamics and parallelism in a connectionist sequential machine, Proceedings of the 8th Annual Conference of the Cognitive Science Society, pp.531-546, N.J. Hillsdale: Lawrence Erlbaum Associates, 1986.

[26] J.-S.R. Jang: IEEE neural networks council standards committee,[online]. Available: http://neural. cs.nthu. edu.tw/jang/benchmark/.

[27] M.A. Kaboudan: Genetic programming prediction of stock prices, Computational Economics 16, pp.207236,2000 .

[28] A. Kasperski, M. Makuchowski and P. Zielinski: A tabu search algorithm for the minmax regret minimum spanning tree problem with interval data, Journal of Heuristics 18, pp.593-625, 2012.

[29] H. Katagiri, T. Hayashida, I. Nishizaki and Q.Q. Guo:
A hybrid algorithm based on tabu search and ant colony optimization for $\mathrm{k}$ - minimum spanning tree problems, Expert Systems with Applications 39, pp.5681-5686, 2012.

[30] H. Katagiri, I. Nishizaki, T. Hayashida and T. Kadoma: Multiobjective evolutionary optimization of training and topology of recurrent neural networks for timeseries prediction, The Computer Journal 55, pp.325336, 2012.

[31] J. Kluabwang, D. Puangdownreong and S. Sujitjorn: Multipath Adaptive Tabu Search for a Vehicle Control Problem, Journal of Applied Mathematics, doi: 10.1155/2012/731623 [online], 2012.

[32] Y.-S Lee and L. - I. Tong: Forecasting energy consumption using a grey model improved by incorporating genetic programming, Energy Conversion and Management 52, pp.147-152, 2011

[33] M.C. Mackey and L. Glass: Oscillation and chaos in physiological control systems, Science 197, pp.287289, 1977.

[34] G. Mani: Learning by gradient descent in function space, in Proceedings of IEEE International Conference, System, Man, and Cybernetics, Los Angeles, CA, pp.242-247, 1990.

[35] 大倉, 岩波：進化型人工神経回路網の構造進化のため の一手法一二十倒立振子問題への適用一, システム制 御情報学会論文誌 19, pp.51-58, 2006.

[36] D.-C. Park: Structure optimization of BiLinear recurrent neural networks and its application to ethernet network traffic prediction, Information Science, doi: 10.1016/j.ins.2009.10.005, 2009.

[37] D.V. Prokhorov, E.W. Saad and D.C. Wunsch: Comparative study of stock trend prediction using time delay, recurrent and probabilistic neural networks, IEEE Transaction of Neural Networks 9, pp.14561470, 1998.

[38] A. Rajavelu, M.T. Musavi and M.V. Shirvaikar: A neural network approach to character recognition, Neural Networks 2, pp.387-393, 1989.

[39] S. Sarkka, A. Vehtari and J. Lampinen: Competitive study of stock trend prediction using time delay recurrent and probabilistic neural networks, Proceedings of International Joint Conference on Neural Networks \& IEEE International Conference on Fuzzy Systems, Budapest, Hungary, pp.1615-1619, 2004.

[40] K. Stanley and R. Miikkulainen: Evolving neural networks through augmenting topologies, Evolutionary Computation 10, pp.99-127, 2002.

[41] K. Stanley and R. Miikkulainen: Efficient reinforcement learning through evolving neural network topologies, Proceedings of the Genetic and Evolutionary Computation Conference (GECCO-2002), Morgan Kaufmann, 2002.

[42] M.H. Sun: A tabu search heuristic procedure for the capacitated facility location problem, Journal of Heuristics 18, pp.91-118, 2012.

[43] J. Suykens: International workshop on advanced balckbox techniques for nonlinear modeling: theory and apploications, 1998 [online]. 
Available: http://www.esat.kuleuven.ac.be/sista/ workshop/index.html.

[44] B. de Vries and J.C. Principe: A theory for neural networks with time delays, Proceedings of the 1990 Conference on Advance in Neural Information Processing Systems 3, San Francisco, CA, USA, pp.162-168, 1990.

[45] D. Whitley, T. Starkweather and C. Bogard: Genetic algorithms and neural networks: Optimizing connections and connectivity, Parallel Computation 14, pp.347-361, 1990.

[46] J.D. Wichard and M. Ogorzalek: Time series prediction with ensemble models, Proceedings of International Joint Conference on Neural Networks \& IEEE International Conference on Fuzzy Systems, Budapest, Hungary, pp.1625-1630, 2004.

[47] A. Wright: Genetic algorithms for real parameter optimization, Foundations of Genetic Algorithms: Proceedings of the First Workshop on the Foundations of Genetic Algorithms and Classifier Systems, G.J.E. Rawlin (Ed.), Morgan Kaufmann, Los Altos, CA, pp.205-218, 1990.

[48] X. Yao: Evolving Artificial Neural Networks, Proceedings of the IEEE 87, pp.1423-1447, 1999.

[49] X. Yao and Y. Liu: A new evolutionary system for evolving artificial neural networks, IEEE Transactions on Neural Networks 8, pp.694-713, 1997.

[50] A. Zeng, R. Goodman and P. Smyth: Discrete recurrent neural networks for grammatical inference, IEEE Transactions on Neural Networks 5, pp.320-330, 2008.
[51] E. Zitzler and L. Thiele: Multiobjective evolutionary algorithms: a comparative case study and the strength Pareto approach, IEEE Transactions on Evolutionary Computation 3, pp.257-271, 1999.

[52］進化技術ハンドブック基礎編, 電気学会進化技術応用 調查専門委員会 (編), 近代科学社, 2010 .

[53] J. Choi, K. Ko and I. Hong: Equalization techniques using a simplified bilinear recursive polynomial perceptron with decision feedback, Proceedings of International Joint Conference on Neural Networks, [online] doi:10.1109/IJCNN.2001.938834, 2001.

[54] NOAA satellite and information service, [online]. Available: http://www.ngdc.noaa.gov/ngdc.html.

[55] Gas Furnace Data, [online]. Available: http://www. austincc.edu/gcepparo/Series J.htm.

[56] Time Series Data Library, [online]. Available: http://robjhyndman.com/TSDL/.

（2014年 5 月28日 受付）

(2015年 4 月22日 採録)

[問い合わせ先］

干739-8527 東広島市鏡山1-4-1

広島大学大学院工学研究院電気電子システム数理部門

林田 智弘

TEL : 082-424-5267

FAX : 082-422-7195

E-mail : hayashida@hiroshima-u.ac.jp 


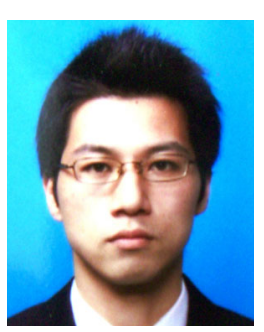

\section{林智智弘 $[$ 正会員 $]$}

2004年広島大学工学部卒業, 2006年 同大学院工学研究科博士課程前期修 了. 同年広島大学大学院工学研究科助 手，2007年助教，2015年准教授となり， 現在に至る。博士(工学)。意思決定沶 よびマルチエージェントシステムに関 する研究に従事。

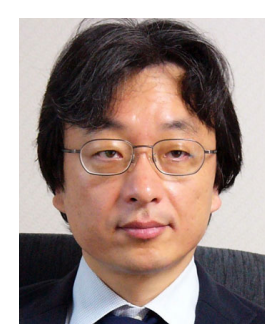

皆崎 一ち万う郎 [正会員]

1982年神戸大学工学部卒業, 1984 年同大学院工学研究科修士課程修了. 同年新日本製鐵株式会社入社，1990年 京都大学経済研究所助手, 1993年摂 南大学経営情報学部助教授, 1997年 広島大学工学部助教授を経て, 2002年 同大学大学院工学研究科教授となり, 現在に至る. 博士 (工学). 意思決定打 よびゲーム理論に関する研究に従事.

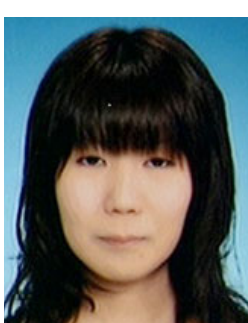

热掠 明意 [非会員]

2010年 岡山県立大学情報工学部卒 業. 同年広島大大学院工学研究科博士 課程前期システムサイバネティクス専 攻入学. 機械学習手法の開発に関する 研究に従事.

\section{Structural Optimization of Recurrent Neural Networks Using Tabu Search by}

\section{Tomohiro HAYASHIDA, Ichiro NISHIZAKI and Akie SUEMUNE}

Abstract :

A recurrent neural network which its structure and link weights between units are appropriately determined has the ability to adequately predict for time-series data. It is difficult to find an optimal structure of the recurrent neural network minimizing both of the training and the generalization errors. In this paper, we propose an optimization method for structural design of neural networks for time-series data by employing tabu search with efficient neighborhood search. To demonstrate the efficiency and effectiveness of the proposed method, we apply our method to several benchmark problems of time-series data and it delivers superior or equal performance to other existing structural optimization methods.

Keywords : Recurrent neural network, structural optimization, tabu search, time-series prediction, evolutionary algorithm

Contact Address : Tomohiro HAYASHIDA

Tomohiro Hayashida, Department of System Cybernetics, Graduate School of Engineering, Hiroshima University

1-4-1, Kagamiyama, Higashihiroshimia, Hiroshima, 739-8527, Japan

TEL : +81-82(424)5267

FAX : +81-82(422) 7195

E-mail : hayashida@hiroshima-u.ac.jp 